This Accepted Author Manuscript is copyrighted and published by Elsevier. It is posted here by agreement between Elsevier and University of Brasilia. Changes resulting from the publishing process - such as editing, corrections, structural formatting, and other quality control mechanisms - may not be reflected in this version of the text. The definitive version of the text was subsequently published in [Theriogenology, Volume 61, Issue 6, 15 April 2004, Pages 10091024, doi:10.1016/j.theriogenology.2003.04.001].You may download, copy and otherwise use the AAM for non-commercial purposes provided that your license is limited by the following restrictions:

(1) You may use this AAM for non-commercial purposes only under the terms of the CC-BY-NCND license.

(2) The integrity of the work and identification of the author, copyright owner, and publisher must be preserved in any copy.

(3) You must attribute this AAM in the following format: [agreed attribution language, including link to CC BY-NC-ND license + Digital Object Identifier link to the published journal article on Elsevier's ScienceDirect ${ }^{\circledR}$ platform].

Este Manuscrito do Autor Aceito para Publicação (AAM) é protegido por direitos autorais e publicado pela Elsevier. Ele esta disponível neste Repositório, por acordo entre a Elsevier e a Universidade de Brasília. As alterações decorrentes do processo de publicação - como a edição, correção, formatação estrutural, e outros mecanismos de controle de qualidade - não estão refletidas nesta versão do texto. A versão definitiva do texto foi posteriormente publicado em [Theriogenology, Volume 61, Número 6, 15 de abril de 2004, Páginas 1009-1024, doi:10.1016/j.theriogenology.2003.04.001]. Você pode baixar, copiar e utilizar de outra forma o AAM para fins não comerciais, desde que sua licença seja limitada pelas seguintes restrições:

(1) Você pode usar este AAM para fins não comerciais apenas sob os termos da licença CC- BYNC-ND.

(2) A integridade do trabalho e identificação do autor, detentor dos direitos autorais e editor deve ser preservado em qualquer cópia.

(3) Tem de atribuir este AAM no seguinte formato: [acordo na linguagem atribuída, incluindo o link para CC BY-NC-ND licença Digital + DOI do artigo publicado na revista Elsevier ScienceDirect ${ }^{\circledR}$ da plataforma]. 


\title{
Cryopreservation of caprine ovarian tissue using glycerol and ethylene glycol
}

\author{
A.P.R Rodrigues \\ C.A Amorim \\ S.H.F Costa \\ M.H.T Matos \\ R.R Santos \\ C.M Lucci \\ S.N Báo \\ O.M Ohashi \\ J.R Figueiredo
}

\begin{abstract}
Cryopreservation of ovarian tissue may be a potential alternative for the conservation of genetically superior animals, including high milk- and meat-producing goat breeds. However, until now, no information was available concerning the cryopreservation of preantral follicles (PF) enclosed in caprine ovarian tissue. The objective of the present study was to evaluate the structural and ultrastructural characteristics of caprine PF after exposure to and cryopreservation of ovarian tissue in 1.5 and $3 \mathrm{M}$ glycerol (GLY) and ethylene glycol (EG). At the slaughterhouse, each ovarian pair from five adult mixed breed goats was divided into nine fragments and randomly distributed into treatment groups. One fragment was immediately fixed for histological examination and ultrastructural analysis, after slaughter (control). Four of the ovarian fragments were equilibrated at $20^{\circ} \mathrm{C}$ for $20 \mathrm{~min}$ in $1.8 \mathrm{ml}$ of MEM containing 1.5 or $3 \mathrm{M} \mathrm{GLY}$ or EG for a toxicity test and the final four fragments were slowly frozen using these cryoprotectants at the concentrations above. After toxicity testing and freezing/thawing, the ovarian fragments were fixed for histological examination. Histological analysis showed that after toxicity testing and cryopreservation of the ovarian tissue in GLY or EG at both concentrations, the percentage of normal PF was significantly lower than controls. Ultrastructural analysis of PF frozen in 1.5 and $3 \mathrm{M} \mathrm{GLY}$, as well as $3 \mathrm{M}$ EG demonstrated that these follicles remained morphologically normal. In conclusion, we demonstrated cryopreservation of caprine PF in ovarian tissue.
\end{abstract}

Keywords: Preantral follicles; Cryopreservation; Cryoprotectants; Caprine; Ovarian tissue

\section{Introduction}

In an attempt to protect biodiversity and to assure the preservation of a species, cryotechnology has been extensively used for male and female gamete conservation; this has allowed the development of germplasm banks of valuable animal stocks and endangered species. Several studies have reported successful cryopreservation of metaphase II oocytes [1], [2], [3] and [4]. However, it is well known that in metaphase II oocytes, the chromosomes are aligned along a delicate spindle of microtubules that are sensitive to cooling and the cryoprotective solutions [5] usually used in cryopreservation protocols. 
It has been suggested that preservation of female gametes may be better achieved by storing pieces of ovarian tissue, containing numerous immature small oocytes enclosed in preantral follicles (PF) [6]. These oocytes are less differentiated, possess fewer organelles, lack a zona pellucida and cortical granules, and are less active metabolically. All these characteristics are potentially beneficial to the freezing/thawing process [7], [8] and [9]. Gosden et al. [10] demonstrated that the fertility of ovariectomized sheep can be restored after cryopreservation and transplantation of ovarian fragments containing immature oocytes enclosed in preantral follicles. Although there has been some success in ovarian tissue cryopreservation, several studies [11], [12], [13], [14] and [15] indicated that follicular damage occurs after freezing and thawing. Such damage can occur during any of step of the cryopreservation process (exposure of the tissue to the cryoprotectant, freezing or thawing). To improve the efficiency of this procedure, it is necessary to identify and to quantify oocyte losses at different stages of cryopreservation.

Most protocols for ovarian tissue cryopreservation utilize permeable cryoprotectants at a concentration of $1.5 \mathrm{M}$ and do not report the effect of other concentrations of cryoprotectant [15], [16] and [17]. Some authors [12] and [18] affirm that GLY is less permeable than other cryoprotectan such as EG, and consequently, not suitable for the cryopreservation of ovarian tissue. However, none of the cryoprotectants noted have been tested on caprine ovarian tissue. Moreover, most reports are based on histological findings [17], [19], [20], [21], [22], [23] and [24], that are less reliable than transmission electron microscopy (TEM). Therefore, the objective of this study was to evaluate the structural and ultrastructural characteristics of caprine preantral follicles after exposure and cryopreservation of the ovarian tissue in GLY and EG at concentrations of 1.5 and $3 \mathrm{M}$.

\section{Materials and methods}

\subsection{Source and preparation of ovarian tissue}

Caprine ovaries $(n=10)$ from adult mixed breed goats $(n=5)$ were obtained at a local abbatoir. The ovaries were trimmed, and washed in $70 \%$ alcohol and then in phosphate buffered saline (PBS). Subsequently, the ovarian pair from each animal was divided into nine fragments of approximately 3-mm thickness ( Fig. 1). For fresh controls (Treatment 1: T1), one ovarian fragment was taken randomly and immediately fixed for $24 \mathrm{~h}$ in Trump McDowell fixative solution (TMFS) for histological examination. From this fragment, a small piece was taken and fixed in a paraformaldeyde/glutaraldeyde solution (2\% paraformaldeyde and $2.5 \%$ 
glutaraldeyde in $0.1 \mathrm{M}$ cacodylate buffer, $\mathrm{pH}$ 7.2) for TEM. The other eight fragments were transported to the laboratory within $1 \mathrm{~h}$ in PBS at $20^{\circ} \mathrm{C}$ and submitted to toxicity testing $(\mathrm{n}=4)$ or freezing-thawing $(n=4)$, as described in the following section.

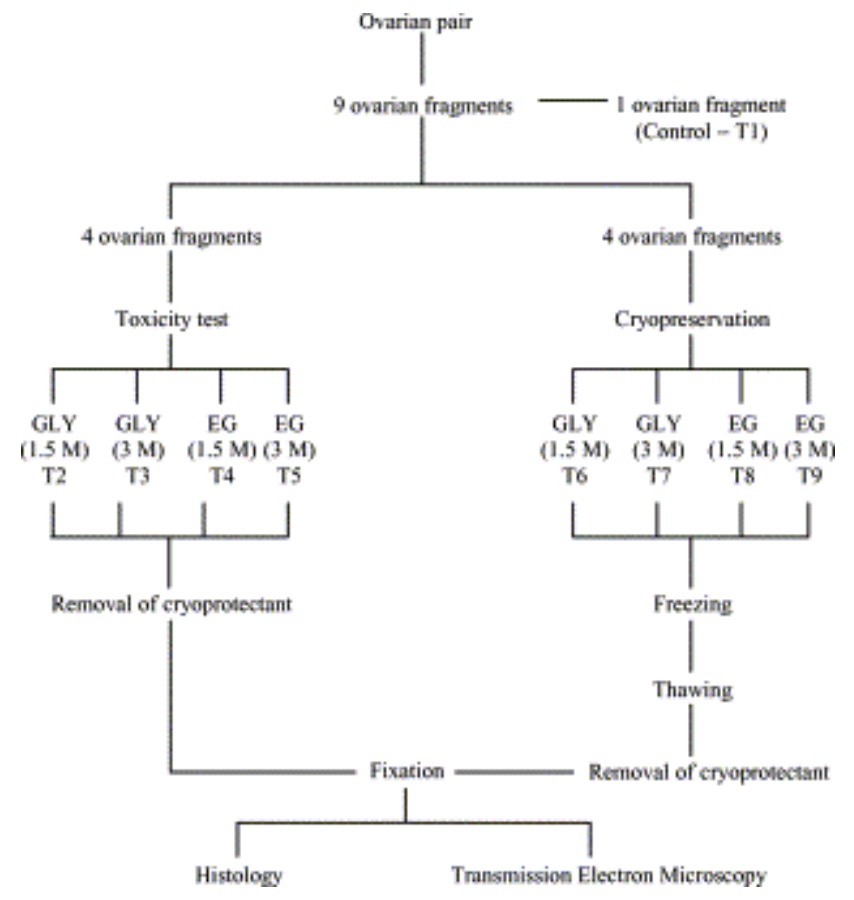

Fig. 1. Experimental design for toxicity testing and cryopreservation of goat preantral follicles enclosed in ovarian tissue.

\subsection{Toxicity test}

The toxicity test was performed to evaluate the effect of the exposure of ovarian tissue to glycerol (GLY) or ethylene glycol (EG), without freezing, on the percentage of normal follicles. For this test, ovarian fragments $(n=4)$ were exposed for $20 \mathrm{~min}$ at $20^{\circ} \mathrm{C}$ (equilibration period) in $1.8 \mathrm{ml}$ of MEM with GLY or EG, both at 1.5 or $3 \mathrm{M}$ (T2-T5). After the equilibration period, cryoprotectants were immediately removed from the tissue according to the method described by Candy et al. [12]. The fragments were washed three times for $5 \mathrm{~min}$ in minimum essential medium (MEM) supplemented with $10 \%$ fetal bovine serum (FBS-MEM+) at room temperature. Finally, the ovarian fragments were fixed in TMFS for histological examination.

\subsection{Freezing and thawing procedures}

For freezing, ovarian fragments $(n=4)$ were placed individually in $2.0 \mathrm{ml}$ vials and equilibrated in $1.8 \mathrm{ml} \mathrm{MEM+} \mathrm{with} \mathrm{cryoprotectants} \mathrm{(GLY} \mathrm{or} \mathrm{EG)} \mathrm{at} \mathrm{the} \mathrm{concentrations} \mathrm{and}$ equilibration period used in the toxicity test (T6-T9). After the equilibration period, the vials containing the ovarian tissue were transferred to a biological programmable freezer (Freeze 
Control, CryoLogic Pty Ltd., Waverley, Australia) at $20^{\circ} \mathrm{C}$. The vials were cooled at $2{ }^{\circ} \mathrm{C} / \mathrm{min}$ to $-7{ }^{\circ} \mathrm{C}$ and ice crystal formation (seeding) was induced manually by touching the vials with forceps pre-chilled in liquid nitrogen. The specimens were held at this temperature for $15 \mathrm{~min}$, then cooled at $0.3{ }^{\circ} \mathrm{C} / \mathrm{min}$ to $-30{ }^{\circ} \mathrm{C}$ and thereafter at $0.15{ }^{\circ} \mathrm{C} / \mathrm{min}$ to $-33^{\circ} \mathrm{C}$. The vials were plunged directly into liquid nitrogen $\left(-196^{\circ} \mathrm{C}\right)$ and stored for up to 5 days before thawing. The freezing curve used in this study was chosen because most procedures currently used to cryopreserve oocytes [25], [26], [27], [28], [29] and [30] and ovarian tissue [10], [11], [12], [14], [15], [18], [24], [31], [32] and [33] stipulate a cooling rate of $0.3-0.5^{\circ} \mathrm{C} / \mathrm{min}$ from the seeding temperature (usually -5 to $-9{ }^{\circ} \mathrm{C}$ ) to a lower temperature, usually between -30 and $-40{ }^{\circ} \mathrm{C}$.

For thawing, the vials were taken from the liquid nitrogen, warmed rapidly at room temperature for $1 \mathrm{~min}$ and immersed in water bath at $37{ }^{\circ} \mathrm{C}$ until the ice melted. The cryoprotectant was then removed as described above for toxicity testing and fixed for histological examination and TEM. Each treatment was repeated five times.

\subsection{Histological analysis}

Ovarian tissue from all treatments was fixed in TMFS for $24 \mathrm{~h}$ to evaluate the quality of goat preantral follicles inside the ovarian tissue. After fixation, fragments were dehydrated, diafanized and embedded in paraffin wax. Serial sections $(7 \mu \mathrm{m})$ of ovarian tissue were cut and every fifth section was mounted on glass slides and stained with periodic acid Schiff (PAS)hematoxylin. All sections were examined using a light microscope at magnifications 20x and 40x. Thirty preantral follicles in each replicate were evaluated per treatment (T1-T9). Preantral follicles were classified as either an oocyte surrounded by one flattened and/or cuboidal layer or several layers of only cuboidal granulosa cells. To avoid counting a follicle more than once, preantral follicles were counted only in the sections where the oocyte nuclei were seen. Follicular quality was evaluated based on morphological features such as integrity of the oocyte, granulosa cells and basement membrane. Preantral follicles were classified as morphologically normal (preantral follicles containing an intact oocyte and granulosa cells without pyknotic nuclei), degenerated Grade 1 follicles (preantral follicles characterized by pyknosis of the oocyte nucleus) and degenerated Grade 2 (preantral follicles characterized by oocyte nucleus pyknosis plus oocyte shrinkage, with or without detachment of granulosa cells from the basement membrane). 


\subsection{Ultrastructural analysis}

For a better evaluation of follicular morphology, ultrastructural analysis was performed using ovarian fragments from control groups and cryopreservation treatments. Tissue fragments with a maximum dimension of $1 \mathrm{~mm} 3$ were fixed in $2 \%$ paraformaldeyde and $2 \%$ glutaraldeyde in $0.1 \mathrm{M}$ sodium cacodylate buffer $(\mathrm{pH}$ 7.2) for $3 \mathrm{~h}$. After fixation and several washes, specimens were post-fixed in $1 \%$ osmium tetroxide, $0.8 \%$ potassium ferricyanide and $5 \mathrm{mM}$ calcium chloride in $0.1 \mathrm{M}$ sodium cacodylate buffer for $1 \mathrm{~h}$. Subsequently, the samples were dehydrated through a gradient of acetone solutions and the tissues were embedded in Spurr. Semi-thin sections $(3 \mu \mathrm{m})$ were stained with toluidine blue. The ultra-thin sections $(60-$ $70 \mathrm{~nm}$ ) were cut and stained with uranyl acetate and lead citrate, and examined under a Jeol JEM $100 \mathrm{C}$ transmission electron microscope.

\subsection{Statistical analysis}

The effect of type (GLY and EG) and concentration (1.5 and $3 \mathrm{M}$ ) of cryoprotectant on the percentage of normal and degenerated Grades 1 and 2 preantral follicles were analyzed by Chi-square test, using data from five replicates. Values were considered statistically significant when $\mathrm{P}<0.05$.

\section{Results}

\subsection{Morphological aspects of normal and degenerated Grades 1 and 2 preantral} follicles

A total of 1350 preantral follicles were examined in the five replicates. Histological analysis of the ovarian tissue indicated that normal (Fig. 2A) and degenerated Grade 1 (Fig. 2B) and Grade 2 follicles (Fig. 2C) were found in controls as well as after toxicity testing and cryopreservation. Combined for all data, the distribution of normal and degenerated Grades 1 and 2 preantral follicles was 89,4 , and $7 \%$ for control, 52,6 and $42 \%$ for toxicity test, and 39 , 15 and $46 \%$ for cryopreservation, respectively. Of the total degenerated follicles (especially related to the oocyte compartment), $14 \%$ had only nuclear pyknosis and $16 \%$ had oocyte shrinkage associated with nuclear pyknosis. Considering both compartments (oocyte and granulosa cells), $63 \%$ of the follicles had pyknosis in the oocyte nucleus plus oocyte shrinkage 
and detachment of granulosa cells from the basement membrane, $2 \%$ detachment of granulosa cells from the basement membrane accompanied by oocyte shrinkage, and $5 \%$ detachment of granulosa cells from the basement membrane, accompanied by pyknosis in the oocyte nucleus. The major finding observed by ultrastructural analysis of degenerated follicles was an intense vacuolization in the oocyte cytoplasm and loss of granulosa cell contents.
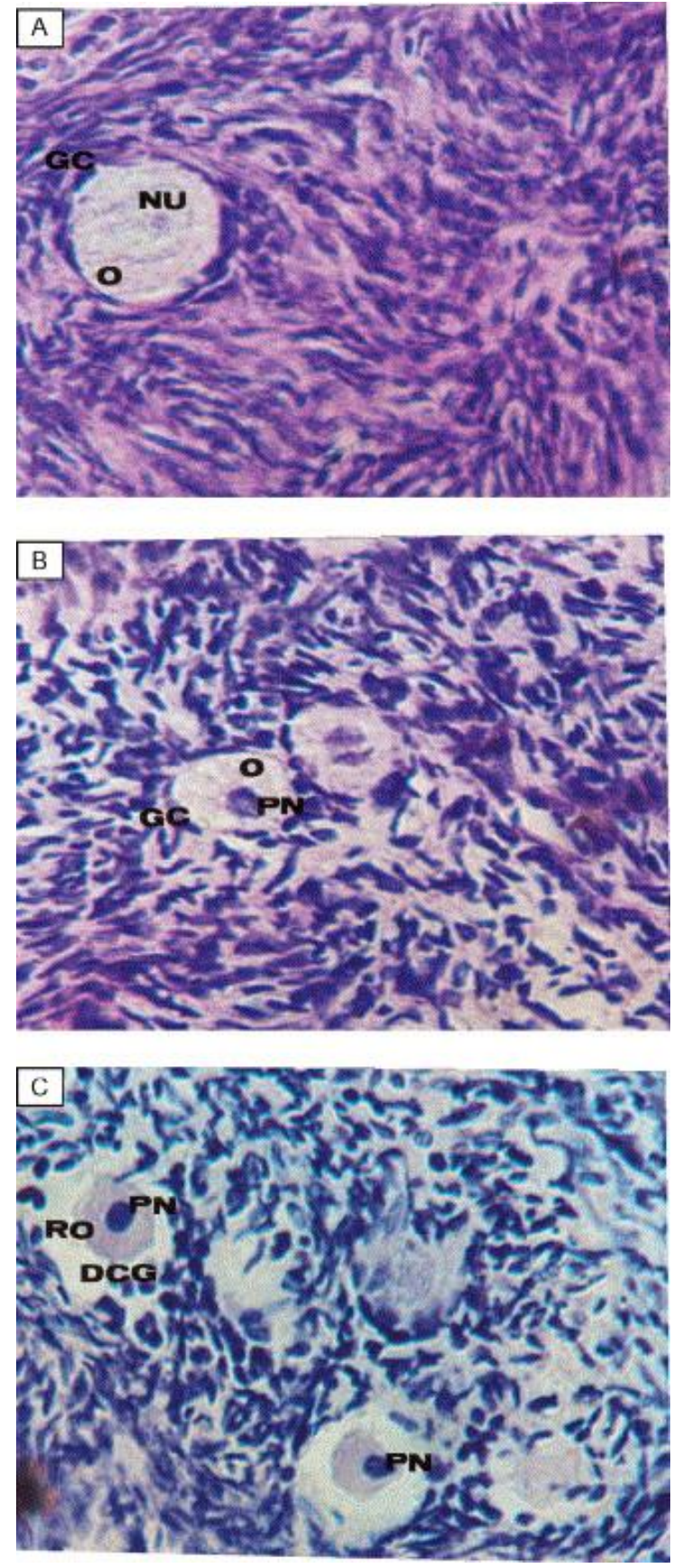

Fig. 2. Histological sections of goat normal (A) and degenerated Grade 1 (B) and degenerated Grade 2 (C) preantral follicles after cryopreservation (magnification: 400x). O: normal oocyte; NU: nucleus of normal oocyte; GC: granulosa cells; RO: retraced oocyte; PN: pycnotic nucleus; DGC: disorganized granulosa cells. 


\subsection{Percentage of normal preantral follicles after toxicity testing and cryopreservation}

The percentage of normal preantral follicles analyzed by histological analysis in controls as well as after toxicity testing and cryopreservation is shown in Table 1. Exposure to GLY or EG in both concentrations (toxicity testing) reduced $(P<0.05)$ the percentage of normal preantral follicles compared to controls. For both cryoprotectants, the percentage of normal follicles was lower $(P<0.05)$ for hen $3 \mathrm{M}$ versus $1.5 \mathrm{M}$. When the cryoprotectants were compared to each other at the same concentration, the percentage of normal follicles was higher $(P<0.05)$ in $E G$ than $G L Y$ for both concentrations. When both cryoprotectants were compared between the different concentrations, the percentage of normal preantral follicles was higher $(P<0.05)$ in $1.5 \mathrm{M} \mathrm{EG}$ compared to $3 \mathrm{M} \mathrm{GLY}$. However, in $3 \mathrm{M} \mathrm{EG}$, the percentage of normal preantral follicles was similar to that observed in $1.5 \mathrm{M} \mathrm{GLY}$ ( Table 2).

Table 1

Normal preantral follicles (\%) in control, after toxicity testing and cryopreservation, as determined by histological evaluation

\begin{tabular}{|c|c|c|c|c|c|}
\hline & \multicolumn{4}{|l|}{ Cryoprotectant } & \multirow[t]{3}{*}{ Control } \\
\hline & \multicolumn{2}{|l|}{ GLY } & \multicolumn{2}{|l|}{ EG } & \\
\hline & $1.5 \mathrm{M}$ & $3 \mathrm{M}$ & $1.5 \mathrm{M}$ & $3 \mathrm{M}$ & \\
\hline $\begin{array}{l}\text { After toxicity } \\
\text { testing }\end{array}$ & $51^{*, a d}(76 / 150)$ & $33^{* b, d}(50 / 150)$ & $75^{* e, d}(112 / 150)$ & $51^{*}$,ad $(77 / 150)$ & $89(134 / 150)$ \\
\hline $\begin{array}{l}\text { After } \\
\text { cryopreservation }\end{array}$ & $41^{* \text { the }}(61 / 150)$ & $36^{* a, b, e}(54 / 150)$ & $31^{*}+{ }^{*} \times(47 / 150)$ & $47^{*}, \mathrm{~b}, \mathrm{e}(70 / 150)$ & $89(134 / 150)$ \\
\hline
\end{tabular}

Values within rows $(a, b, c)$ are different $(P<0: 05)$.

Values within columns $(d, e)$ are different $(P<0: 05) . *$

$P<0: 05$, significantly differs from control

Table 2.

Grades 1 and 2 preantral follicles (\%) in controls, after toxicity testing and cryopreservation

\begin{tabular}{|c|c|c|c|c|c|c|c|c|c|}
\hline & \multirow[t]{3}{*}{ Control } & \multicolumn{4}{|c|}{ Toxicity testing } & \multicolumn{4}{|c|}{ Cryopreservation } \\
\hline & & \multicolumn{2}{|l|}{ GLY } & \multicolumn{2}{|l|}{ EG } & \multicolumn{2}{|l|}{ GLY } & \multicolumn{2}{|l|}{ EG } \\
\hline & & $1.5 \mathrm{M}$ & $3 \mathrm{M}$ & $1.5 \mathrm{M}$ & $3 \mathrm{M}$ & $1.5 \mathrm{M}$ & $3 \mathrm{M}$ & $1.5 \mathrm{M}$ & $3 \mathrm{M}$ \\
\hline Grade 1 & $4^{d}$ & $1^{2, d, f, r}$ & $6^{a, b, b, f}$ & $3^{\text {and, }}$ & $13^{* b, b, r, r}$ & $15^{*} \times 2,48$ & $7^{a, a, a, r}$ & $34^{*, b, d, g}$ & $6^{\mathrm{c}, \mathrm{d}, \mathrm{f}}$ \\
\hline Grade 2 & $\begin{array}{l}(6 / 150) \\
7^{4}\end{array}$ & $\begin{array}{l}(2 / 150) \\
48^{*} * 4, f\end{array}$ & $\begin{array}{l}(9 / 150) \\
61^{*}, a, c, r\end{array}$ & $\begin{array}{l}(5 / 150) \\
22^{*, b, e, f}\end{array}$ & $\begin{array}{l}(19 / 150) \\
36^{\circ}, c, e, r\end{array}$ & $\begin{array}{l}(23 / 150) \\
44^{*}, \text { ahe, }\end{array}$ & $\begin{array}{l}(11 / 150) \\
57^{*}, a, c, r\end{array}$ & $\begin{array}{l}(61 / 150) \\
35^{*}, \mathrm{~b}, \mathrm{c}, \mathrm{ds}\end{array}$ & $\begin{array}{l}(9 / 150) \\
47^{*}, \mathrm{~b}, \mathrm{~b}, \mathrm{~s}\end{array}$ \\
\hline
\end{tabular}

Different superscripts $(a, b, c)$ differ significantly at the same cryoprotectant and same concentration.

Different superscripts (d, e) differ significantly between Grades 1 and 2 degeneration.

Different superscripts ( $f, g$ ) differ significantly between toxicity test and cryopreservation. *

$P<0: 05$, significantly differs from control

After freezing and thawing, the percentage of normal follicles was lower $(P<0.05)$ than in fresh ovarian tissue (controls). After cryopreservation, the percentage of normal preantral 
follicles did not differ among treatments, except for 3 M EG, which had a significantly higher percentage of normal follicles than 1.5 M EG.

When comparisons were made between toxicity testing and cryopreservation using the same cryoprotectants and concentrations, in 1.5 M EG the percentage of normal preantral follicles was lower $(P<0.05)$ after freezing and thawing when compared to toxicity testing.

\subsection{Distribution of follicular degeneration grade in controls, after toxicity testing and cryopreservation}

Fig. 3 shows the distribution of degenerated Grades 1 and 2 preantral follicles in controls and after toxicity testing and cryopreservation. The percentage of degenerated Grade 1 follicles in controls was lower $(P<0.05)$ than in 3 M EG after toxicity testing and 1.5 M GLY and EG after cryopreservation. After toxicity testing and cryopreservation, the percentage of degenerated Grade 2 follicles treatments was higher $(P<0.05)$ than the controls. There was no significant difference between percentages of degenerated Grades 1 and 2 follicles in controls.

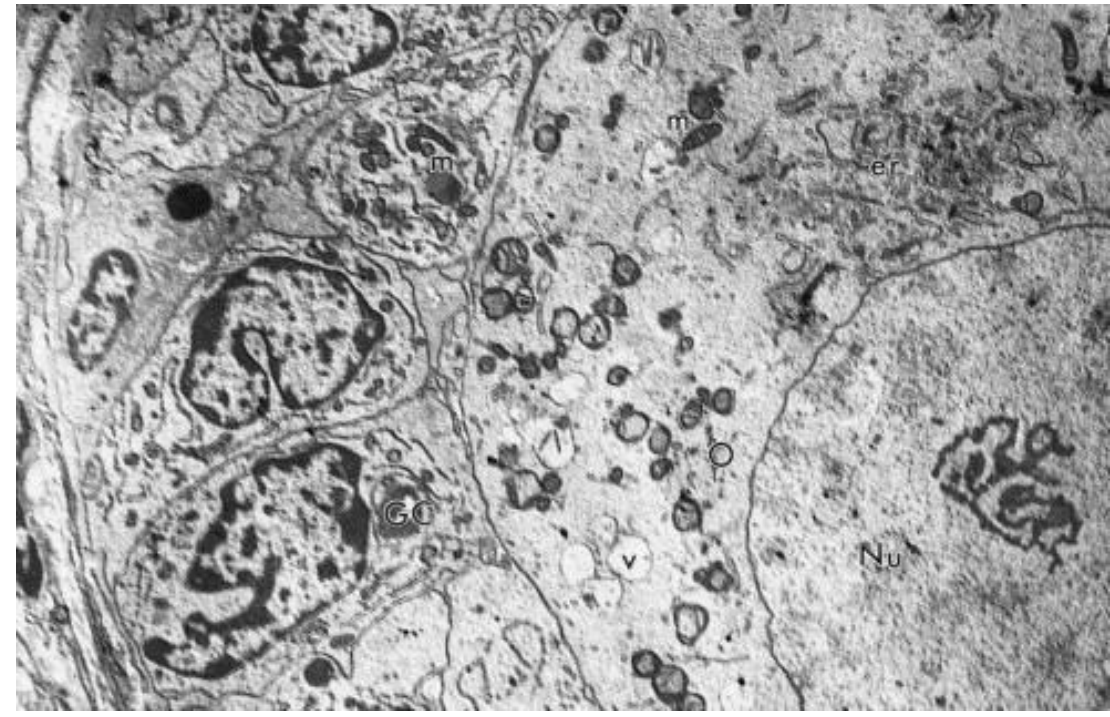

Fig. 3. Electron micrograph of a follicle from control group. O: oocyte, GC: granulosa cells, Nu: nucleus, m: mitochondria, er: endoplasmic reticulum, v: vesicles (magnification: 3400×).

Exposure of ovarian tissue to 1.5 M EG (toxicity testing) had a lower percentage $(P<0.05)$ of degenerated Grades 1 and 2 follicles when compared to $3 \mathrm{M}$. The percentage of Grade 2 degeneration was higher $(P<0.05)$ in $G L Y$ than in EG at both concentrations. With regard to the distribution of follicular degeneration grades for each treatment, for both cryoprotectants and concentrations, the percentage of degenerated Grade 2 follicles was higher $(P<0.05)$ than degenerated Grade 1 follicles.

In contrast to observations in the toxicity test, after cryopreservation with $1.5 \mathrm{M} \mathrm{EG}$, a greater percentage $(P<0.05)$ of degenerated Grade 1 follicles was found in $3 \mathrm{M} \mathrm{EG}$, as well as in 
1.5 M GLY. Regarding Grade 2 degeneration, when the concentrations were compared to each other in the cryoprotectant, no significant difference was observed. The percentage of Grade 2 follicles was higher $(P<0.05)$ when compared to Grade 1 follicles in all treatments for both cryoprotectants and concentrations, except for 1.5 M EG.

When comparisons were made between toxicity testing and cryopreservation in the same cryoprotectant and concentration, in $1.5 \mathrm{M} \mathrm{GLY}$ and EG, the percentage of degenerated Grade 1 follicles in the toxicity test was lower $(P<0.05)$ than after cryopreservation. Similar results were also observed in degenerated Grade 2 follicles in 1.5 and 3 M EG.

\subsection{Ultrastructural analysis of the ovarian tissue}

Only preantral follicles from controls (Fig. 3) and those frozen in 1.5 and $3 \mathrm{M} \mathrm{GLY} \mathrm{(Fig.}$ 4A and B), as well as 3 M EG (Fig. 4D) appeared morphologically normal after ultrastructural analysis. These follicles exhibited a large number of mitochondria and some vesicles distributed through the ooplasm. Transmission electron microscopy revealed that follicles from ovarian tissue frozen at 1.5 M EG considered normal at histological analysis (Fig. 4C) were extremely vacuolated. In some cases, the fusion of these vacuoles produced an empty area. Sometimes this alteration was associated with the loss of granulosa cell content and, in some cases, with oocyte nucleus shrinkage (data not shown). In order to verify that the deleterious effect of 1.5 M EG occurred in toxicity testing, ultrastructural analysis was also performed in the ovarian tissue from this treatment. The ultrastructure of normal preantral follicles in the ovarian tissue exposed to $1.5 \mathrm{M} \mathrm{EG}$ was similar to controls, indicating that the ultrastructural change occurred during the cryopreservation process. 

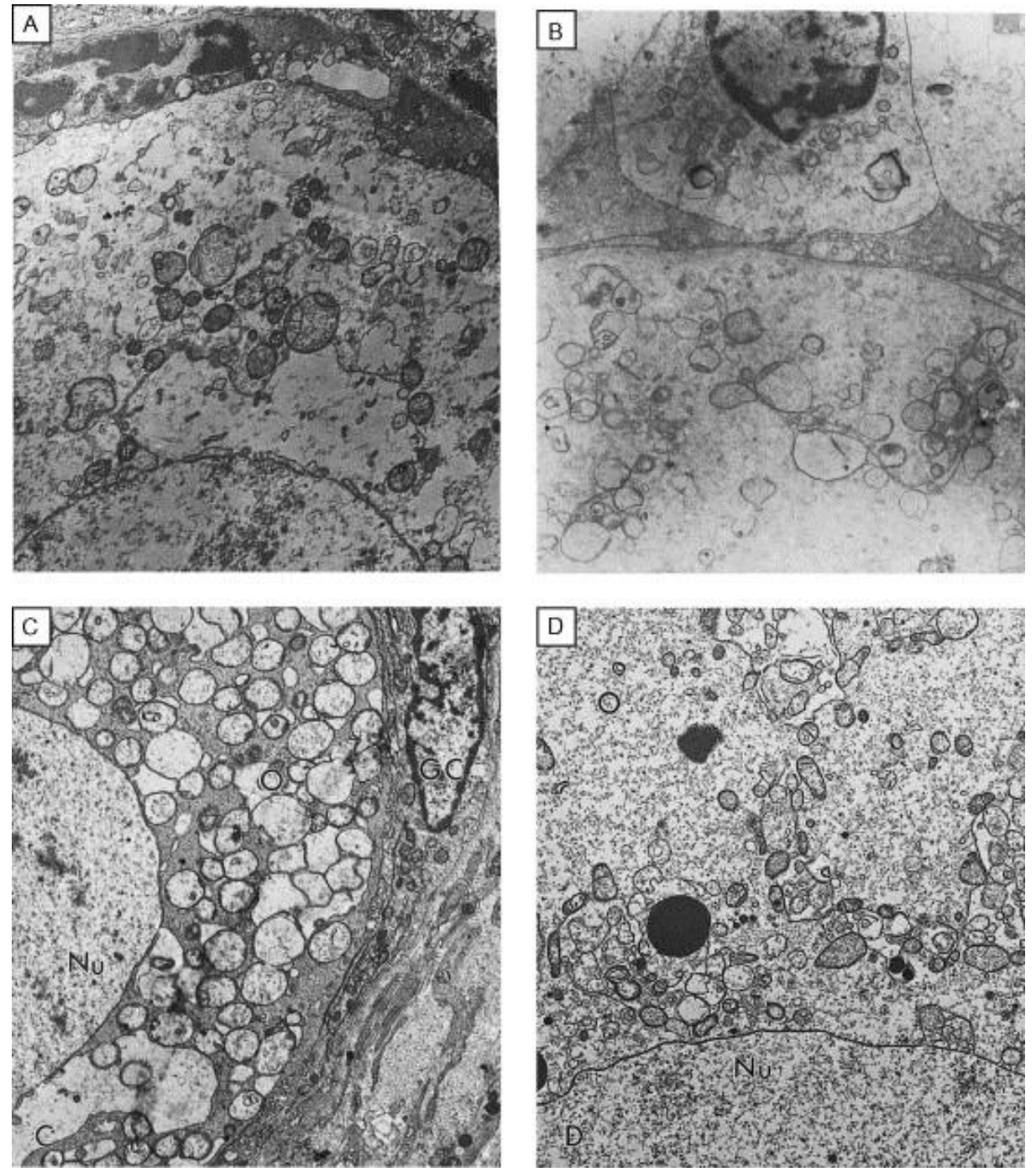

Fig. 4. Electron micrographs of follicle cryopreserved with (A) $1.5 \mathrm{M}$ glycerol, (B) $3 \mathrm{M}$ glycerol, (C) $1.5 \mathrm{M}$ ethylene glycol, and (D) $3 \mathrm{M}$ ethylene glycol. O: oocyte, GC: granulosa cells, Nu: nucleus (magnification: $3400 \times$ ).

\section{Discussion}

The present study was the first report of toxicity testing and cryopreservation in GLY and EG of caprine preantral follicles enclosed in ovarian tissue. Although degenerated follicles were observed during exposure to cryoprotectants and after freezing and thawing, a normal morphologic appearance was maintained in 31\% (EG: $1.5 \mathrm{M}$ ) to 47\% (EG: $3 \mathrm{M}$ ) of the preantral follicle population after freezing and thawing. Normal follicles obtained after freezing/thawing indicated that the morphology was similar to that observed in vivo. In addition, our preliminary results demonstrated the ability of cryopreserved follicles to survive after in vitro culture.

Toxicity testing revealed that all treatments had a toxic effect on caprine preantral follicles; there was a significant reduction in morphologically normal follicles. Cryoprotectants can chemically interact with important biomolecules in cells or tissues and exert toxic effects 
[34] if they are used in high [4] or inadequate concentrations. Besides concentration, temperature and duration of exposure to a certain cryoprotectant can also influence its toxicity [35]. Therefore, we suggest that the temperature $\left(20^{\circ} \mathrm{C}\right)$ and the time $(20 \mathrm{~min})$ of exposure used in the present study may not be appropriate for GLY and EG at the tested concentrations, since the percentage of morphologically normal preantral follicles was lower than for controls. The percentage of normal preantral follicles after cryopreservation was also significantly lower than in controls. However, that reduction had already been observed immediately after exposure to the cryoprotectant, indicating that cryopreservation was not the only factor responsible for the loss of follicular viability. Contrary to our findings, Hovatta et al. [14] observed no difference in the percentage of normal and atretic preantral follicles in human ovarian tissue before and after freezing. These results may be due to the differences between species, as well as to the cryopreservation protocol (type and time of exposure to cryoprotectant, slower freezing curve and a multistep process removal of cryoprotectant) used. The successful cryopreservation of oocytes has also been previously reported. Candy et al. [25], working with mouse oocytes, showed that the rate of maturation to metaphase II was not significantly different between frozen and fresh oocytes ( $83 \%$ versus $74 \%$ ). Additionally, the in vitro fertilization rate was similar for frozen and fresh oocytes (70\% versus $81 \%$ ). In other studies, there was successful cryopreservation of oocytes of several species, with live births reported for mice [36], rabbits [37], and cows [1]. The success obtained in these experiments may be due to the cryopreservation protocols being more appropriate for the developmental stage of the oocytes and the preservation forms used (oocytes without cumulus cells), as well as to intrinsic characteristics of each species.

With regard to the toxicity test, $3 \mathrm{M} \mathrm{GLY}$ and EG were more toxic to ovarian tissue than 1.5 M. However, after cryopreservation, 3 M EG was more efficient at maintaining follicle integrity than 1.5 M EG, suggesting that 1.5 M EG provided less protection of caprine ovarian tissue against cryoinjury or thawing. A concentration of 3 M EG is probably more effective than 1.5 M EG at reducing intracellular ice formation (IIF). The cryoprotectants diffuse across cell membranes in exchange for cell water. This displacement of water by cryoprotectants, in addition to freezing point depression, decreases the possibility of IIF and maintains cell volume during freezing, avoiding damage [38]. For caprine ovarian tissue, we speculate that a higher concentration of EG may be necessary. Toxicity testing also demonstrated that 1.5 and $3 \mathrm{M} \mathrm{EG}$ were more efficient than GLY (at the same concentrations) for maintaining normal morphology of the preantral follicles. However, after cryopreservation, the efficiency of these two cryoprotectants was similar. The present study demonstrated the importance of the toxicity test; it showed that exposure to cryoprotectants can have deleterious effects on ovarian 
tissues that can compromise the cryopreservation procedure. However, it also demonstrated that toxicity testing could not predict the ideal cryoprotectant and concentration for cryopreservation. Toxicity testing verified that $1.5 \mathrm{M}$ EG was better than $3 \mathrm{M} \mathrm{EG}$ or 1.5 and $3 \mathrm{M}$ GLY. After cryopreservation, alterations were intensified during the other phases of the cryopreservation process, but only at concentrations of $1.5 \mathrm{M} \mathrm{EG}$; this may be due to the inadequacy of time $(20 \mathrm{~min})$, and temperature $\left(20^{\circ} \mathrm{C}\right)$ of exposure to $1.5 \mathrm{M} \mathrm{EG}$, or the combination of those factors with the cooling rate used.

In all treatments, from the toxicity test to after cryopreservation, the percentage of degenerated Grade 2 follicles was greater $(P<0.05)$ than that of controls, demonstrating that the toxic effect of the cryoprotectant can be detrimental for both follicular compartments (oocyte and granulosa cells); this may be due to osmotic damage caused by GLY and EG. During exposure to cryoprotectants, cells initially lose water and shrink to compensate for the high extracellular osmolarity caused by the cryoprotectants [39]. Considering these normal events and the present results, we suggest that the concentrations of cryoprotectants, temperature and time of exposure tested were not optimal for caprine preantral follicles.

When comparisons were performed between the cryoprotectants at both concentrations (1.5 M GLY×3 M EG and $3 \mathrm{M} \mathrm{GLY \times 1.5} \mathrm{M} \mathrm{EG),} \mathrm{after} \mathrm{toxicity} \mathrm{testing} \mathrm{the}$ percentage of Grade 1 preantral follicles was significantly superior in 3 M GLY and EG when compared, respectively, to $1.5 \mathrm{M}$ EG and GLY. On the contrary, after cryopreservation, $1.5 \mathrm{M}$ GLY and EG were, respectively, more harmful than $3 \mathrm{M} \mathrm{EG}$ and GLY, indicating that for ovarian tissue needs a higher concentration of each cryoprotectant for cryopreservation, probably due to the occurrence of IIF. According to Mazur [40], the two main causes of cellular death during freezing and thawing are solution effects and IIF.

Regarding the percentage of Grade 2 degeneration after toxicity testing, the rate was significantly higher for 1.5 and $3 \mathrm{M} \mathrm{GLY}$ when compared respectively, to 3 and $1.5 \mathrm{M}$ EG. After cryopreservation, the percentage of degenerated Grade 2 follicles was also significantly greater for $3 \mathrm{M}$ versus $1.5 \mathrm{M}$ EG. On the other hand, the percentage of follicles with degeneration Grade 2 in 3 M EG was similar to that found for ovarian tissue cryopreserved in 1.5 M GLY. Therefore, GLY was more toxic for ovarian tissue than EG. This may have been due to the low permeability of GLY; this could have increased osmotic stress during addition, thawing and removal of the cryoprotectant, since the influx of water is faster than the efflux of GLY from the cells [12] and [41].

The cryopreservation of ovarian tissue in $1.5 \mathrm{M} \mathrm{GLY}$ and EG resulted in a significant increase in the percentage of preantral follicles with Grade 1 degeneration when compared to the toxicity test. Therefore, to obtain a lower percentage of degenerated Grade 1 follicles, we 
could utilize a higher cryoprotectant concentration, although the percentage of normal preantral follicles, for both 1.5 and $3 \mathrm{M} \mathrm{GLY}$, was similar. Similar results were observed for follicles with Grade 2 degeneration, in the presence of 1.5 and $3 \mathrm{M} \mathrm{EG}$, for both toxicity testing and cryopreservation. These results may be due to ice crystal formation between follicular cells and within follicular cells and the oocyte. Sugimoto et al. [13] demonstrated that the formation of ice in the intercellular space could easily damage the cells and destroy cell-cell communication, which is essential to maintain tissue integrity. Ovarian tissue, like other tissues, is a complex system of organized cells that requires coordinated interactions between the cells and the extracellular matrix to maintain function [42]. Addition of cryoprotectant prior to cooling and its removal after warming involves coupled membrane transport of water and the cryoprotectant; if performed improperly, this can result in deleterious cell volume changes [43]. Some cell types are damaged by the cell shrinkage induced by cryoprotectant addition. However, cell swelling during removal of cryoprotectant is more likely to be deleterious [44].

The follicular degeneration (nuclear pyknosis and oocyte shrinkage) detected in the present study were also described by other authors after cryopreservation of human [14] and non-human primate ovarian tissue [11]. Additionally, the degeneration in the granulosa cell layer (detachment and disorganization) observed in our study has also been detected after vitrification of murine [13] and slow freezing of bovine [15] ovarian tissue. The system used to classify degenerated follicles (Grades 1 and 2 ) was similar to that described by Paynter et al. [15] for bovine degenerated follicles in cryopreserved ovarian tissue. However, there was an important difference between the classifications. In the present study, alterations in the granulosa cells of the main follicular category used (i.e. primordial follicles) were always accompanied by oocyte shrinkage and/or pyknosis. In contrast, Paynter et al. [15] used primary and secondary bovine follicles. This result may be due to the differences between species, as well as to the developmental stage of the follicles used in the cryopreservation procedure.

Histology did not reveal qualitative differences between different cryoprotectants and concentrations in preantral follicles (soon after cryopreservation), except between 1.5 and $3 \mathrm{M}$ EG. However, TEM revealed that follicles cryopreserved in 1.5 M EG had many signs of ultrastructural abnormality, such as the presence of numerous vacuoles in the oocyte cytoplasm. Hay et al. [45] and Assey et al. [46] demonstrated that cytoplasmic vacuoles are also a characteristic sign of degeneration in both granulosa and cumulus cells during degeneration in vivo. According to Fuku et al. [47], in bovine cryopreserved oocytes, these vacuoles may represent altered mitochondria. The ultrastructural analysis also demonstrated 
that the ultrastructural morphology of cryopreserved follicles in 3 M EG was better preserved than that of follicles cryopreserved in 1.5 M EG and GLY at both concentrations. Hovatta et al. [14] reported that histology is relatively uninformative if performed immediately after the thawing; sudden changes in the organelles can appear even several hours after thawing. Therefore, when TEM is not available, it is advisable to maintain the ovarian tissue in an incubator prior to fixation [14]. In addition, using different cryopreservation protocols from that used in the present study, others have demonstrated the inefficiency of GLY in the cryopreservation of female gametes [48] and [49]. Parrot [48] showed that $80 \%$ of the oocytes present in mice ovarian tissue were destroyed after exposure to $1.6 \mathrm{M} \mathrm{GLY}$ for $1.5 \mathrm{~h}$ at room temperature. In nonhuman primates (Rhesus and Cynomolgus monkeys) the deleterious effect of GLY was also demonstrated in cooling of immature oocytes. In these species, the actin filament system was distorted in oocytes exposed to 1.0 and $2.0 \mathrm{M} \mathrm{GLY}$ at $23^{\circ} \mathrm{C}$ [49]. Previous work with mature caprine oocytes indicated that the permeability of GLY was highly dependent on temperature, and at $20{ }^{\circ} \mathrm{C}$ [4] and $4{ }^{\circ} \mathrm{C}$ [16], this cryoprotectant has lower permeability than EG. Newton et al. [18] compared the efficiency of four cryoprotectants (DMSO, propanediol, EG and GLY) in the cryopreservation of human ovarian tissue; they showed that EG had better results because it penetrated more quickly in the tissue, due probably to its lower molecular weight [50]. Based on the literature [12] and [16], EG was more effective at protecting cells during cryopreservation than GLY, perhaps due to its low toxicity and efficient permeability [51]. Although some authors [12], [16] and [18] have shown that GLY is inferior to the other cryoprotectants, in our study the percentage of normal preantral follicles after cryopreservation in GLY was similar to EG. It is noteworthy that we used a different slow freezing curve and a removal procedure for GLY similar to the employed by Candy et al. [12]. However, results obtained by Candy et al. [12] using GLY (4.3-28.3 and 16.3-32\%: survival of primordial and primary follicles, respectively) were comparable to those for caprine preantral follicles in our experimental conditions. Another report in human ovarian tissue [18] using a freezing protocol similar to Candy et al. [12], i.e. slow freezing curve and fast removal of GLY without sucrose, obtained only $10 \%$ viable preantral follicles after freezing and thawing. Similarly to Candy et al. [12] and Newton et al. [18], in the present study we used an initial cooling rate of $2{ }^{\circ} \mathrm{C} / \mathrm{min}$ to the seeding temperature and a cooling rate of $0.3^{\circ} \mathrm{C} / \mathrm{min}$ from the seeding temperature $\left(-7^{\circ} \mathrm{C}\right.$ in this experiment) to a lower temperature. However, unlike previous studies in which the ovary was cooled to $-140^{\circ} \mathrm{C}$ [18] or $-150^{\circ} \mathrm{C}$ [12] before storage in liquid nitrogen, in our study the ovarian tissue was cooled to $-33{ }^{\circ} \mathrm{C}$. According to Shaw et al. [52], although cells cooled in this way still contain some water when they are plunged into liquid nitrogen, there is not enough intracellular water to cause damage 
(providing that appropriate rapid warming protocols are used). However, the cryopreservation procedure used in this work might be improved by testing different freezing curves, removal procedures of cryoprotectan, and equilibration periods.

In conclusion, we demonstrated that caprine preantral follicles in ovarian tissue can be cryopreserved using GLY and EG. Based on these results, cryopreservation of caprine ovarian tissue can be a feasible alternative for preservation of female genetic material, with the opportunity to subsequently restore ovarian activity via transplant and/or in vitro maturation of preantral follicles enclosed in the ovarian tissue.

\section{Acknowledgements}

This work was supported by CNPq. Ana Paula R. Rodrigues is a recipient of a grant from FUNCAP of Brazil. The authors thank Dr. Edilberto Silveira, Ph.D. (CENAUREMN), Dr. José F. Nunes, Ph.D. (LATSCO) and AKZO-NOBEL for the logistical support. We are grateful to Z.R. Madeira and Dr. Matthew Wheeler, Ph.D. for reviewing the manuscript.

\section{References}

[1] Fuku E, Kojima T, Shioya Y, Marcus GJ, Downey BR. In vitro fertilization and development of frozen-thawed bovine oocytes. Cryobiology 1992;29:485-92.

[2] Carroll J, Gosden RG. Transplantation of frozen-thawed mouse primordial follicles. Hum Reprod 1993;8:1163-7.

[3] Nowshari MA, Nayudu PL, Hodges JK. Effect of cryoprotectant concentration, equilibration time and thawing procedure on survival and development of rapid frozen-thawed mature mouse oocytes. Theriogenology 1994;42:1193-204.

[4] Le Gal F, Gasqui P, Renard JP. Evaluation of intracellular cryoprotectant concentration before freezing of goat mature oocyte. Cryo-Letters 1995;16:3-12.

[5] Newton $\mathrm{H}$. The cryopreservation of ovarian tissue as a strategy for preserving the fertility of cancer patients. Hum Reprod Update 1998;4:237-47.

[6] Paynter SJ. Current status of the cryopreservation of human unfertilized oocytes. Hum Reprod Update 2000;6:449-56.

[7] Oktay K, Nugent D, Newton H, Salha O, Chatterjee P, Gosden RG. Isolation and characterization of primordial follicles from fresh and cryopreserved human ovarian tissue. Fertil Steril 1997;67:481-6.

[8] Oktay K, Newton H, Ausbard Y, Salha O, Gosden RG. Cryopreservation of immature human oocytes and ovarian tissue: an emerging technology? Fertil Steril 1998;354:1-7. 
[9] Liu J, Van der Elst J, Van den Broecke R, Dumortier F, Dhont M. Maturation of mouse primordial follicles by combination of grafting and in vitro culture. Biol Reprod 2000;62:121823.

[10] Gosden RG, Baird DT, Wade JC, Webb R. Restoration of fertility to oophorectomized sheep by ovarian autografts stored at 196 8C. Hum Reprod 1994;9:597-603.

[11] Candy CJ, Wood MJ, Whittingham DG. Follicular development in cryopreserved marmoset ovarian tissue after transplantation. Hum Reprod 1995;9:2334-8.

[12] Candy CJ, Wood MJ, Whittingham DG. Effect of cryoprotectants on the survival of follicles in frozen mouse ovaries. J Reprod Fertil 1997;110:11-9.

[13] Sugimoto $M$, Miyamoto $H$, Kabasawa $T$, Manabe $N$. Follicle survival in neonatal rat ovaries cryopreserved by vitrification. Cryo-Letters 1996;17:93-8.

[14] Hovatta O, Silye R, Krausz T, Abir R, Margara R, Trew G, et al. Cryopreservation of human ovarian tissue using dimethylsulphoxide and propanediol-sucrose as cryoprotectant. Hum Reprod 1996;11: 1268-72.

[15] Paynter SJ, Cooper A, Fuller B, Shaw RW. Cryopreservation of bovine ovarian tissue: structural normality of follicles after thawing and culture in vitro. Cryobiology 1999;38:301-9.

[16] Newton H, Fisher J, Arnold JRP, Pegg DE, Faddy MJ, Gosden RG. Permeation of human ovarian tissue with cryoprotective agents in preparation for cryopreservation. Hum Reprod 1998;13:376-80.

[17] Salle B, Lornage JA, Demirci B, Vaudoyer F, Poirel MT, Franck M, et al. Restoration of ovarian steroid secretion and histologic assessment after freezing, thawing and autograft of a hemi-ovary in sheep. Fertil Steril 1999;72:366-70.

[18] Newton H, Aubard Y, Rutherford A, Sharma V, Gosden R. Low temperature storage and grafting of human ovarian tissue. Hum Reprod 1996;11:1487-91.

[19] Cox SL, Shaw J, Jenkin G. Transplantation of cryopreserved fetal ovarian tissue to adult recipients in mice. J Reprod Fertil 1996;107:315-22.

[20] Gunasena KT, Lakey JRT, Villines PM, Crister ES, Cristse JK. Allogeneic and Xenogeneic transplantation of cryopreserved ovarian tissue to athymic mice. Biol Reprod 1997;57:226-31.

[21] Salle B, Lornage J, Franck M, Isoard L, Rudigoz RC, Guerin JF. Freezing, thawing, and autograft of ovarian fragments in sheep: preliminary experiments and histologic assessment. Fertil Steril 1998; 70:124-8.

[22] Oktay K, Newton H, Gosden RG. Transplantation of cryopreserved human ovarian tissue results in follicle growth initiation in SCID mice. Fertil Steril 2000;73:599-603.

[23] Van den Broecke R, Liu J, Handyside A, Van der Elst C, Krausz T, Dhont M, et al. Follicular growth in fresh and cryopreserved human ovarian cortical grafts transplanted to immunodeficient mice. Eur J Obstet Gyn Reprod Biol 2001;97:193-201. 
[24] Demirci B, Salle B, Frappart L, Franck M, Guerin JF, Lornage J. Morphological alterations and DNA fragmentation in oocytes from primordial and primary follicles after freezing-thawing of ovarian cortex in sheep. Fertil Steril 2002;77:595-600.

[25] Candy CJ, Wood MJ, Whittingham DG, Merriman JA, Choudhury N. Cryopreservation of immature mouse oocytes. Hum Reprod 1994;9:1738-42.

[26] Baka SG, Toth TL, Veeck LL, Jones HW, Muasher Jr SJ, Lanzendorf SE. Evaluation of the spindle apparatus of in-vitro matured human oocytes following cryopreservation. Hum Reprod 1995;10:1816-20.

[27] Son WY, Park SE, Lee KA, Lee WS, Ko JJ, Yoon TK, et al. Effects of 1,2-propanediol and freezing-thawing on the in vitro development capacity of human immature oocytes. Fertil Steril 1996;66:995-9.

[28] Porcu E, Fabbri R, Seracchioli R, Ciotti PM, Magrini O, Flamigni C. Birth of a healthy female after intracytoplasmic sperm injection of cryopreserved human oocytes. Fertil Steril 1997;68:724-6.

[29] Stachecki JJ, Cohen J, Willadsen SM. Cryopreservation of unfertilized mouse oocytes: the effect of replacing sodium with choline in the freezing medium. Cryobiology 1998;37:346-54.

[30] Lanzendorf SE, Mayer JF, Toner J, Oehninger S, Saffan DS, Muasher S. Pregnancy following transfer of ooplasm from cryopreserved-thawed donor oocytes into recipient oocytes. Fertil Steril 1999;71:575-7.

[31] Newton H, Picton H, Gosden RG. In vitro growth of oocyte-granulosa cell complexes isolated from cryopreserved ovine tissue. J Reprod Fertil 1999;115:141-50.

[32] Liu J, Van der Elst J, Van den Broecke R, Dhont M. Live offspring by in vitro of oocytes from cryopreserved primordial mouse follicles after sequential in vivo transplantation and in vitro maturation. Biol Reprod 2001;64:171-8.

[33] Cleary M, Snow M, Paris M, Shaw J, Cox S-L, Jenkin G. Cryopreservation of mouse ovarian tissue following prolonged exposure to an ischemic environment. Cryobiology 2001;42:12133.

[34] Karow AM. Pharmacological interventions in vitro. In: Karow AM, Crister JK, editors. Reproductive tissue banking. London: Academic Press; 1997. p. 167-227.

[35] Rall WF. Factors affecting the survival of mouse embryos cryopreserved by vitrification. Cryobiology 1987;24:387-402.

[36] Whittingham DG. Fertilization in vitro and development to term of unfertilized mouse oocytes previously stored at 196 8C. J Reprod Fertil 1977;49:89-94.

[37] Vicent C, Garnier V, Heyman Y, Renard JP. Solvent effects on cytoskeletal organization and in-vivo survival after freezing of rabbit oocytes. J Reprod Fertil 1989;87:809-20.

[38] Karow AM, Shlafer M. Ultrastructure-function correlative studies for cardiac cryopreservation. IV. Prethaw ultrastructure of myocardium cooled slowly ( $28 \mathrm{C} / \mathrm{min}$ ) or rapidly $(708 \mathrm{C} / \mathrm{s}$ ) with or without dimethyl sulfoxide (DMSO). Cryobiology 1975;12:130-43. 
[39] Sze'll A, Shelton JN. Role of equilibration before rapid freezing of mouse embryos. J Reprod Fertil 1986;78:699-703.

[40] Mazur P. Cryobiology: the freezing of biological systems. Science 1970;168:939-49.

[41] Gosden RG. Low temperature storage and grafting of human ovarian tissue. Mol Cell Endocrinol 2000;163:125-9.

[42] Acker JP, Larese A, Yang H, Petrenko A, McGam LE. Intracellular ice formation is affected by cell interactions. Cryobiology 1999;38:363-71.

[43] Paynter SJ, Fuller BJ, Shaw RW. Temperature dependence of mature mouse oocyte membrane permeability in the presence of cryoprotectant. Cryobiology 1997;34:122-30.

[44] Armitage WJ, Juss BK, Easty DL. Differing effects of various cryoprotectants on intracellular junctions of epithelial (MDCK) cells. Cryobiology 1995;32:52-9.

[45] Hay MF, Cran DG, Moor RM. Structural changes occurring during atresia in sheep ovarian follicles. Cell Tissue Res 1976;169:515-29.

[46] Assey RJ, Hytell P, Kanuya N. Oocyte structure in dominant and subordinate follicles in zebu cattle (Bosindicus). Anat Embryol 1994;190:461-8.

[47] Fuku E, Xia L, Downey BR. Ultrastructural changes in bovine oocytes cryopreserved by vitrification. Cryobiology 1995;32:139-56.

[48] Parrot DMV. The fertility of mice with orthotopic ovarian grafts derived from frozen tissue. J Reprod Fertil 1960;1:230-41.

[49] Younis AL, Toner M, Albertini DF, Biggers JD. Cryobiology of non-human primate oocytes. Hum Reprod 1996;11:156-65.

[50] Massip A. Cryopreservation of embryos of farm animals. Reprod Domest Anim 2001;36:49-55.

[51] Bautista JAN, Kanagawa H. Current status of vitrification of embryos and oocytes in domestic animals: ethylene glycol as an emerging cryoprotectant of choice. Jpn J Vet Res 1998;45:183-91.

[52] Shaw JM, Oranratnachai A, Trounson AO. Fundamental cryobiology of mammalian oocytes and ovarian tissue. Theriogenology 2000;53:59-72. 